\title{
Factors and Barriers to Adoption of E-Commerce: The Case of Developing Countries
}

\author{
Prof: LI ZHI WEN \\ School of Management, Jiangsu University \\ PO box: 212013, Zhenjiang, 01 Xuefu Road, Jiangsu Province, China. \\ AKOUATCHA GUY HAROLD Phd Student \\ School of Management, Jiangsu University \\ PO box: 212013, Zhenjiang, 01 Xuefu Road, Jiangsu Province, China \\ COULIBALY TIEFIGUE PIERRETTE Phd Student \\ School of Management, Jiangsu University \\ PO box: 212013, Zhenjiang, 01 Xuefu Road, Jiangsu Province, China
}

\begin{abstract}
$\underline{\text { Abstract }}$
The Internet has revolutionized the world of business, reducing time and distance. This new tool gives access to a wealth of information and facilitate communication across the globe. It opened the door to a new aspect of trade practice called "electronic commerce", which refers to the exchange of goods and services between two entities via computer networks. This kind of transaction are been adopted by many at a sulfurous rate, affecting important sectors of the economy, such as distribution sector, the banking sector and many more. However, due to the lack of basic infrastructure, inadequate socio-economic conditions and the lack of national strategies by governments in developing countries, e-commerce lags behind. This situation is depriving these developing countries from the benefits and contributions of e-commerce on their economy. The study shows that to understand the adoption and diffusion of e-commerce in developing countries, cultural issues must be considered. In this article, we present and discuss these issues that impede the adoption of e-commerce in developing countries.
\end{abstract}

Key words: Developing countries; E-Commerce; Mobile telephony; Middle class; obstacles

DOI: $10.7176 / \mathrm{DCS} / 9-3-11$

Publication date:March $31^{\text {st }} 2019$

\section{INTRODUCTION}

The countries of the South (term which qualifies developing countries and emergent) knew a large number of transformations during the last three decades: urbanization, emergence of a middle class, reduction of the poverty, rise in the range of the services, the establishment of many e-commerce companies giant, the knowledge economy ...etc.

At the same time that their environment was transformed, the consumers of these regions develop new wants, desires and needs; their behavior changes, in particular with regards to ICTs.

The take-off of the e-commerce constitutes a following stage in this process of economic development and catching up with developed countries.

The countries of the South are confronted indeed today with a double shock. On one hand, that of technological innovations which affect various sectors, of which the business and on the other hand, there is a shock of demand triggered by new practices of the clientele (in particular the youngest), regarding consumption of goods and services via their smartphone. 
Trade becomes at the moment a part of the high-tech industry, anchored in the digitalization of savings (what we are named the digital revolution or the fourth industrial revolution [Schwab, K., 2017 $]$ ]). This is manifested in particular through technological innovations in ICT (internet, mobile telephony), but also more recent ones like, digital platforms, connectivity, automation, algorithm technology, Big Data (big data collected to better understand the customer), Artificial Intelligence, and Blockchain. In such a context, it results from its low production costs compared to traditional production system of companies and it makes entrances easy for new start-ups in markets. Besides, the constraints in terms of distance, cost or asymmetry of information (market failure) disappear for the benefit of the consumer.

At the same time, this digital transformation of economies comes along with a change of consumer behavior via the accessibility of the smartphone. The customer thus has more buying power and no longer hesitates to compare the information he collects as well as the prices of various goods and services. He becomes very demanding, consuming when he wants and where he wants. This consumers' behavior reflects the evolution of the society, what we can name a "uberisation" of the economy ${ }^{6}$ marked by a domination of the consumer, the development of an economy in the demand (request) where the latter decides by opposition to a supply-side economics characterized by a mass production. Besides, this power increased aimed at the customers is translated by a lesser cost of goods and services, thanks to the increase of the competition (competitors) led (inferred) by the entrance (entry) of new actors (start-up) to the side of the traditional companies.

This digital revolution is in particular initiated and dominated by the Giants of the American Net, which we call the GAFA (acronym for Google, Amazon, Facebook and Apple) and which are present in various sectors (telecomICT, health, trade, energy, media, travel-leisure, banking, insurance). By their side and at a lower level, we find the NATU (for Netflix, Airbnb, Tesla, Uber) which is growing very fast. Finally, China is not left out with its own Giants of the web, identified through BATX for Baidu (search engine ${ }^{7}$ ), Alibaba (specialized in e-commerce), Tencent (which offers Internet and mobile services, online advertising) and Xiaomi (mobile, electronic).

In these conditions, the development of e-commerce is a new area that the African continent must take advantage of, in order not to lag behind other developing countries.First of all, we study the key factors leading to the takeoff of online sales in this region, namely the emergence of a middle class, the expansion of the smartphone market and the growth of local players in the sector of e-commerce. In addition, we analyze the obstacles, barriers that hinder the development of e-commerce in this region. In a final section, we alight the challenges to be met in the near future to lead to a trade revolution in this region.

\section{KEY FACTORS IN THE DEVELOPMENT OF E-COMMERCE IN AFRICA}

Electronic commerce started in the first place in developed countries, characterized inter alia by: - (I) mature markets with heavily banked consumers with high purchasing power;

- (II) internet access by the population, giving rise to a mass of connected consumers;

- (III) the presence of new players who, through their strategy, have enabled the development of online sales;

- (IV) a network of quality infrastructure, technology and logistics networks to supply and deliver these new customers.

In Europe, competition is strong with key players such as Amazon, Cdiscount, mass-market retailers (Carrefour, Casino, Auchan, Leclerc) and Zalando. It accounts for $15 \%$ of retail sales in the United States, despite a dense store network. However, it already reaches $20 \%$ in China and Africa with a potential of $50 \%$ given the delay in infrastructure (see. section 3). According to a study by McKinsey McKinsey $\left(2013^{8}\right)$, e-commerce could represent $\$ 75$ billion in 2025 in this region.

\footnotetext{
5 Schwab, K. (2017), La quatrième révolution industrielle, Dunod.

[1] This concept is a neologism, a antonomasia, used for the first time in December 2014 by Maurice Lévy during an interview with the

Financial Times [1] which then aired in the current language. It translates the questioning of an economic model following a new digital entrant.
}

Uber in the taxi business. The actors of the Uber-economy are platforms that facilitate the exchange, the transaction between individuals (providers and applicants) through shared relationships (peer-to-peer) in a global and accelerated market.

${ }^{7}$ It is the fourth most visited website in the world behind Facebook, You Tube et Google.

${ }^{8}$ McKinsey Global Institute (2013), Lions go digital: The Internet's transformative potential in Africa, novembre 2013. 
E-commerce thus has a high potential in Nigeria. Indeed, it is the largest market in Africa, both in size of GDP and population. In addition, according to a study conducted on Nigeria by Ipsos on behalf of PayPal, 2/3 of Internet users in Nigeria bought online at least once, there is an e-client base of almost 60 million Nigerians (out of a total population of 180 million).

Among the key factors conducive to the development of e-commerce in Africa, we can identify the emergence of a middle class characterized by:

- The increase of the purchasing power of personal computer equipment and access the Internet to consume online.

- $\quad$ The expansion of the smartphone market.

- $\quad$ and the growth of local operators in the e-commerce sector.

\subsection{The emergence of a middle class in Africa}

According to the report of the African Development Bank (ADB), the middle class, called "the middle of the pyramid" was estimated at $34 \%$ of the population in Africa, which constitute 370 million people (BAD, $2011^{9}$ $2017^{10}$ ) and is a decisive step in the development of the private sector in this region.

Indeed, according to Mthuli Ncube, former vice president of the AfDB, the African middle class would reach 1.1 billion people in 2060 , equivalent to $42 \%$ of the continent's population and would consume $\$ 2.2$ trillion in goods and services, or $3 \%$ of global consumption in 2030.

This category, however, remains fragmented since it is concentrated in urban areas and $60 \%$ of it has a purchasing power of between $\$ 2$ and $\$ 20$ (in purchasing power parity for the reference year). 2005). It is specifically important to distinguish within the middle class in Africa, three subgroups, identified in Table 1 below:

- A lower range (called Floating Class) which lies between 2 (the poverty line) and 4 dollars a day, as defined by Ravallion $\left(2009^{11}\right)$ and which represented in 2010, 204 million inhabitants. This class has emerged from poverty but remains precarious and vulnerable in the event of life-threatening events or negative shocks (unemployment, recession, natural disasters) in the future.

- An intermediate class (Lower Middle) which consumes certain goods, in accordance with the law of Engel $(1857)^{12}$

- and Upper Middle which has more comfortable living conditions.

The last two categories thus represent an estimate of the potential demand for consumer goods. They work in education, health, public service or the private sector. Not to mention the "new rich" who earn more than $\$ 100$ a day and whose lifestyle is characterized by the "4 V" "Voiture, Ville, Voyage, Virement bancaire" that means (Car, City, Travel, Bank Transfer), to use the terminology of Jacquemot (2012 ${ }^{13}$ )

In other words, these are consumer targets for businesses and therefore for e-commerce that implement growth strategies for this clientele. These middle classes are banked (and therefore solvent) and also have durable capital goods such as computers, internet access and smartphones, which are essential supports for Internet consumption. According to the annexed graph 1 and the study by Lufumpa, Mubila et Ben Aïssa $(2015)^{14}$, it turned out that in 2014, North Africa occupied the first position regarding the emergence of this middle class since it concentrated

\footnotetext{
9 Banque Africaine du Développement (2011), "The Middle of the Pyramid: Dynamics of the Middle Class in Africa", 20 avril 2011.

${ }^{10}$ Banque Africaine du Développement (2017), Perspectives Economiques en Afrique, Paris : OCDE, 2017.

${ }^{11}$ Ravallion, M. (2009), 'The Developing World's Bulging (but Vulnerable) « Middle Class »', Policy Research Working Paper no. 4816 .

12 It stipulates that the proportion of income earmarked for food expenditure is lower when income is important.

${ }^{13}$ Jacquemot, P. (2012), "Les classes moyennes changent-elles la donne en Afrique ? Réalité, enjeux et perspectives », Afrique Contemporaine, 244 (4), 17-31.

${ }^{14}$ Lufumpa, L.C., Mubila, M. et Ben Aïssa, M.S. (2015), « The dynamics of the middle class in Africa » in Ncube, M. et Lufumpa, C.L. (ed.), The Emerging Middle Class in Africa, Routledge, African Development Bank.
} 
$77 \%$ of the total middle class in Africa. Specifically, Tunisia had the highest concentration of the middle class, followed by Morocco, Egypt and Algeria. However, this growth of the middle class in this region is strongly correlated with the use of ICT as we now specify it.

Table 1. Distribution of the middle class in Africa by income and by size of population in 2010

\begin{tabular}{|c|c|c|}
\hline Slice of the middle class & Income per day (in \$) & $\begin{array}{c}\text { Population size in Africa in2010 (in } \\
\text { millions of inhabitants) }\end{array}$ \\
\hline Lower & {$[2-4[$} & 204 \\
\hline Intermediate & {$[4-10[$} & 150 \\
\hline Superior & {$[10-20[$} & 16 \\
\hline Total & {$[2-20[$} & 370 \\
\hline
\end{tabular}

Source: AfDB (2011)

\subsection{Explosion of smartphone use in Africa}

The penetration rate (or coverage rate) of mobile telephony has increased from 15 million in 2000 to 850 million people in 2018 in Africa and is characterized by the booming of smartphone market. Indeed, according to the study by Deloitte $\left(2018^{15}\right)$, Africa will have more than 660 million smartphone users by 2020 against 320 million in 2018 , more than double in the space of only two years. In addition, according to the same study, the adoption of smartphones in Africa would reach 54\% in 2020 (compared to 28\% in 2016); Finally, according to the World Bank $\left(2016^{16}\right)$, the proportion of individual Internet users has increased from $7 \%$ to $20 \%$ of the population in Africa between 2010 and 2016, and 460 million Africans will have Internet access via smartphones in 2020 (compared to 340 million in 2016) with a penetration rate of almost 55\% (Deloitte, 2018). This expansion of the Internet therefore offers opportunities in domestic e-commerce, that is to say the e-commerce of goods and services of all types, whether between businesses (B2B - Business to Business), between consumers (C2C - Consumer to Consumer), B2C (Business to Consumer) or consumer to business (C2B - Consumer to Business). The mobile phone usage in Africa's increase to 344\% from 2007 to 2016 . However, while mobile connectivity is well advanced in Africa, as we have just shown, access to the Internet at home remains late (see Table 2 below). Actually, less than $30 \%$ of the African population has access to mobile broadband (compared to $43 \%$ in Asia) and only $15 \%$ have internet at home. This can be explained in particular by two factors noted by Ninot and Peyroux $\left(2018^{17}\right)$ : High rates of broadband and the latest broadcast of smartphones, facilitated in particular by the emergence of a second-hand market as well as by the launching of devices « low cost» made in China (Huawei, Xiaomi).

Table 2. Comparison of Internet access between different regions of the world in 2016

\begin{tabular}{|c|c|c|}
\hline COUNTRIES & $\begin{array}{c}\text { Access to mobile broadband } \\
\text { (as\% of population) }\end{array}$ & $\begin{array}{c}\text { Internet access at home } \\
\text { (in\% of the population) }\end{array}$ \\
\hline Africa & 29 & 15 \\
\hline America & 79 & 64 \\
\hline Asia Pacific & 43 & 46 \\
\hline Europe & 77 & 84 \\
\hline
\end{tabular}

Source: PwC (2016)

\footnotetext{
${ }^{15}$ Deloitte (2018), « TMT Predictions Afrique ».

${ }^{16}$ Banque mondiale (2016), World Development Report: Abbreviated Digital Dividends.

${ }^{17}$ Ninot, O. et Peyroux, E. (2018), «Digital revolution and development in Africa: a singular trajectory », Questions internationales, ${ }^{\circ}$ 90, mars-avril 2018, 44-52.
} 


\section{EMERGENCE OF LOCAL ACTORS IN THE E-COMMERCE SECTOR IN AFRICA}

The disruptive innovation and digital revolution undergoing in Africa are transforming the continent's economic potential by creating new market and consumer targets. This leads groups in the e-commerce sector to rethink their strategies (PwC, 2016). However, exporting the existing e-commerce model, the Amazon type, Alibaba, is not possible because according to Weigert $\left(2018^{18}\right)$, it is unsuited to constraints specific to Africa. In fact, the African model of e-commerce is characterized by door-to-door delivery and by payment in cash on delivery $\left(\mathrm{PwC}, 2016^{19}\right)$. These two specificities about the e-commerce in Africa aren't good catalyst for the expansion of the section, hence the need for enabling infrastructure development from of local and foreign actors. In addition, the breakthrough with the original model of e-commerce to penetrate these specific markets also involves the internationalization of off-line activities. Weigert (2018) notes for example the after-sales service (through the development of call centers and then follow orders), the logistics (purchase of vehicles to route and ensure the payment) or the customer acquisition (via the exhibition of items on stands that will then be sold online). In these conditions, new private actors have reacted and are entering the booming e-commerce sector in Africa, attracted by the explosion in the rate of mobile phone equipment and the increase in the purchasing power of households. According to the report published by Disrupt Africa. $\left(2017^{20}\right), 264$ companies operate in e-commerce in 23 African countries and provide various services (taxi, travel, capital goods, clothing). Some countries (South Africa, Kenya and Nigeria) are the most dynamic. In addition, the players are heterogeneous with the coexistence of both large international groups and startups. In terms of business strategy, some firms are specialized in online commerce from the start, while others have diversified their activities, such as Safaricom, an expert in mobile payments in Kenya, which has developed a digital platform Masoko. Among these local players, we can mention Afrimalin, the main e-commerce platform in French-speaking sub-Saharan Africa but also « la licorne ${ }^{21} »$ African Internet Group, nicknamed "the African Alibaba» (Les Echos, 2018 22), which shows promising future. It is born in effect 2012 in Nigeria through the Jumia platform and is present in twenty-three African countries, including Ivory Coast, Algeria, Egypt and Morocco. Among the shareholders of Jumia, we can list the German Rocket Internet (propeller of several ecommerce sites, including Zalando in Europe), the South African telecom operator MTN, Orange Goldman Sachs, or the insurer Axa. Moreover, unlike Western e-commerce platforms that focus on a single sector (textile, household appliances, food ...), the range of products and services offered on African e-commerce is much larger. Proposed offers must indeed consider the specificities of each country. The services covered are various as well as the marketing of many goods and services, such as job offers, real estate, food delivery ... It should be noted, however, that although the African Internet Group has been increasing its income since its birth in 2012, it has still not breaking even and achieved returned on investments (ROI). Jumia aims in fact for a strategy of anchoring, and of conquest based on the long-term strategy, allowing itself to adapt to the modes of consumption specific to each African country. Also, Jumia is confronted to a stiff competition. We can mention the Casino subsidiary, established since 2014 in French-speaking West Africa. Indeed, Casino and Bolloré have joined forces to launch, via two subsidiaries (respectively Cdiscount Africa and Bolloré Africa Logistics), an e-commerce site in Africa developed under the brand name CDiscount (owned by Casino).

However, according to the Afrishopping report (Disrupt Africa, 2017), only 30\% of start-ups in e-commerce in Africa make profits. Some actors did not have the expected success and preferred abandoned (case of Kalahari in Kenya in 2011 or Mocality in 2013 in South Africa) or reduce their activity (Cdiscount which focuses since 2016 only on Ivory Coast).

\footnotetext{
${ }^{18}$ Weigert, M. (2018), « The invention of African e-commerce by the private se ctor. », Passerelles, Vol. 19 (2).

${ }^{19}$ PwC (2016), "Disrupting Africa: Riding the wave of the digital revolution".

${ }^{20}$ Disrupt Africa (2017)," Afri-Shopping: Exploring the African E-commerce Startup eEcosystem Report".

${ }^{21}$ A start-up whose valuation is over $\$ 1$ billion.

${ }^{22}$ Les Echos (2018), "Jumia establishes itself as the African Alibaba”, October 3, 2018.
} 


\section{OBSTACLES AND BARRIERS TO THE DEVELOPMENT OF ELECTRONIC COMMERCE $\underline{\text { IN AFRICA }}$}

Many obstacles of various kinds, however, can block the development of e-commerce in Africa. First, lack of enabling infrastructure or poor trust of customers in the quality of products in Africa hinders the take-off of ecommerce. Indeed, in this region, the density of road network is the weakest in the world: $7 \mathrm{kms}$ per $100 \mathrm{~km}^{2}$ in 2013, of which only 28\% asphalted according to Agepar (Association of Managers and African Partners of the Road). ICT investments is accounted for between $\$ 1.3$ and $\$ 2.4$ billion between 2012 and 2016, representing between $1.8 \%$ and $3.5 \%$ of total infrastructure investment in Africa. In addition, there are still obstacles to online transactions effectiveness at the operational level, namely the low rate of bank account owners, the still dominant use of cash payment or the customers' feeling of computer insecurity.

In addition, another barrier is the low level of development (characterized by persisting illiteracy and a low level of computer literacy, and the institutional quality of poor institutions and the legal system), which favors an uncertain business climate (Elsmani, R., Rahim et Mahmoud, 2017 ${ }^{23}$ ). The development of e-commerce is hindered by the socio-cultural factor since the market is considered as a place of proximity and socialization.

Lastly, management of the "last mile» (to use the expression of Rosen, 2017 $7^{24}$ ) remains a logistical obstacle to delivery as road infrastructure and postal systems are of low quality. It results from these barriers to the growth of electronic commerce, high transaction costs, geographical constraints or even the weak exchange of information. In fact, according to GeoPoll's 2016 survey of 1,251 people from five African countries (South Africa, Ghana, Kenya, Nigeria and Uganda), the lack of trust and security in e-commerce and payment problems are the two main reasons for the reluctance of these populations to use e-commerce, followed by transport costs. (see Chart $2 \& 3$ in the Annex).

\section{CHALLENGES AND PROSPECTS FOR AFRICA'S E-COMMERCE TAKE-OFF}

The prospects for e-commerce in Africa also lie in the development of new enabling tools, namely mobile payments. Mobile connectivity brings financial inclusion by enabling ICT banks and providers to reach unbanked customers and offer low-cost services. Promoting mobile payment technology increases the volume of unsealed transactions and limits cash flow management costs.

Mobile accounts are more numerous than bank accounts. The smartphone contributes to the banking of the population. We can cite Orange Money, launched in 2008 and present in 17 countries with 40 million customers (Stratégies, $2018^{25}$ ). The Internet and mobile phones are accelerating financial inclusion as revealed in the Global Findex database $\left(2017^{26}\right)$. The share of adults with a mobile bank account has almost doubled to $21 \%$, particularly in the following eight African countries: Burkina Faso, Côte d'Ivoire, Gabon, Kenya, Senegal, Tanzania, Uganda and Zimbabwe.

\footnotetext{
${ }^{23}$ Elsmani, R., Rahim, A. et Mahmoud M. A. (2017), “A Review of the E-commerce Barriers Faced by the SMEs in Africa”, International Journal of Innovation and Business Strategy, Vol. 7 (1).

${ }^{24}$ Rosen, J. (2017), “Ghana’s last mile”, MIT Technology Review, 120 (1).

${ }^{25}$ Stratégies (2018), « Mobile, IA, blockchain...l'Afrique au cœur des tendances », $1^{\text {er }}$ novembre 2018, 24-26.

${ }^{26}$ Demirgüc-Kunt, A., Klapper, L., Singer, D., Ansar, S. et Hess, J. (2017), Global Findex Database 2017: Measuring Financial Inclusion and Techno-Financial Revolution, World Bank Group.
} 
Table 3. Survey of the share of adults (age 15 and over) in sub-Saharan Africa account holders (\% of population)

\begin{tabular}{|l|c|c|c|}
\hline & 2011 & 2014 & 2017 \\
\hline Adults with an account & 23.2 & 34.2 & 42.6 \\
\hline Adults with an account on their mobile & 23.2 & 28.8 & 32.8 \\
\hline Adults with an account with a financial institution & & 11.6 & 20.9 \\
\hline
\end{tabular}

Source: Global Findex Database $(2011,2014,2017)$

In addition, $34.4 \%$ of the adult population made or received digital payments in 2017 compared to $26.9 \%$ in 2014 . In contrast, only $7.6 \%$ of the same population used their mobile phone to perform a digital payment and online order. With the establishment of successful

M-commerce payment platforms, for example through the M-Pesa service, a digital payment platform developed by Safaricom as early as 2007, there has been some progress. One in three people have an account in Kenya. in 2016 even though this country is characterized by one of the highest inclusion rates. According to the World Bank (2016), 10\% of the population in sub-Saharan Africa now has an account for making telephone transactions. This result is a rise in the banking sector in this region, from $24 \%$ in 2011 to $34 \%$ in 2014 . Jumia did not hesitate to go from e- to m-commerce. Another specificity of African Internet Group is that it accepts payment in cash upon receipt of the package ${ }^{27}$ or delivery points relay. Another payment possibility is making transactions based on the diaspora present in a developed country (for example in France, the United Kingdom) for purchases then delivery to Africa. This avoids money transfers between different countries with additional fees. We can cite for example the startup in African market which allows to order articles online from France and to deliver in several countries of French-speaking Africa. Moreover, solar drones offer new prospects for electronic commerce in the delivery of parcels (made in Rwanda) ordered on the internet, even if there is a regulatory vagueness.

Finally, these new challenges and prospects for launching the e-commerce sector in Africa also require the State to support this digital revolution in the establishment of infrastructure, quality telecom and road networks, as well as favorable policies and regulation. This strategic vision, which can be described as "market friendly" (the expression used by the World Bank in $1993^{28}$ during its report on the Asian miracle), will be beneficial for the private and public sectors since the State will perceive, through the take-off from e-commerce more tax revenue. The risk of a digital divide is already present in Africa, as the report of the World Bank (2016) shows. 23\% of Internet users on the continent are urban against $10 \%$ of rural territories. Similarly, only $8 \%$ of Internet users are 45 and over, compared to $20 \%$ for Generation Y. Again, $18 \%$ of Internet users are men and $12 \%$ are women. Finally, from the point of view of households, $11 \%$ of Internet users are among the richest $60 \%$ against $4 \%$ among the $40 \%$ poorest. The state must therefore intervene through public policies and targeted investment to correct such spatial, social, income and educational inequalities (Ponelis et Holmner, 2015 ${ }^{29}$ )

\section{CONCLUSION}

The rise of the internet and the boom of the mobile phone usage in Africa offer great opportunities for e-commerce development. Technological disruption is transforming markets and society in Africa very quickly and opening up commercial potential. This continent has many assets such as urbanization, the development of the middle class, the high demographic proportion of young people or even the presence of local African actors. The potential of Africa in this 21 st century to become a new home of production and consumption, to take off just as Asia was in the late 20th century, is therefore very high. E-commerce players in Africa are targeting internet consumers in the upper middle classes, the wealthiest and the diaspora. Strategies established by local actors to promote the use of internet platforms to consumers must consider the ethnic diversity of potential consumers. However, there are persistent structural barriers in terms of physical infrastructure (transport, logistics) and ICTs, developmental

\footnotetext{
${ }^{27}$ However, with this measure, the dropout rate (return rate) of orders and frauds can become significant....

${ }^{28}$ Banque mondiale (1993), The East Asian Miracle: Economic Growth on Economic Policy, Oxford University Press, New York.

${ }^{29}$ Ponelis, S.R. et Holmner, M.A. (2015), «ICT in Africa: Enabling a Better Life for All », Information Technology for Development, 21 (1), 1-11.
} 
delays or cultural barriers. Internet access, though, helps to remove these obstacles. Among the prospects and challenges in Africa in terms of e-commerce, payment on delivery and via mobile phones are the most promising, as well as the possibility of using solar drones to deliver products ordered over the internet.

\section{REFERENCES}

Banque Africaine du Développement (2011), "The Middle of the Pyramid: Dynamics of the Middle Class in Africa", 20 avril 2011.

Banque Africaine du Développement (2017), Perspectives Economiques en Afrique, Paris : OCDE, 2017.

Banque mondiale (1993), The East Asian Miracle: Economic Growth on Economic Policy, Oxford University Press, New York.

Banque mondiale (2016), World Development Report: Abbreviated Digital Dividends.

Elsmani, R., Rahim, A. et Mahmoud M. A. (2017), “A Review of the E-commerce Barriers Faced by the SMEs in Africa”, International Journal of Innovation and Business Strategy, Vol. 7 (1).

Deloitte (2018), «TMT Predictions Afrique ».

Disrupt Africa (2017),"Afri-Shopping: Exploring the African E-commerce Startup eEcosystem Report”.

Financial Times (2014), « Maurice Lévy tries to pick up Publicis after failed deal with Omnicom », 14 décembre 2014.

Jacquemot, P. (2012), "Les classes moyennes changent-elles la donne en Afrique ? Réalité, enjeux et perspectives », Afrique Contemporaine, 244 (4), 17-31.

Les Echos (2018), "Jumia stands out as the African Alibaba", October 3, 2018.

Lufumpa, L.C., Mubila, M. et Ben Aïssa, M.S. (2015), « The dynamics of the middle class in Africa » in Ncube, M. et Lufumpa, C.L. (ed.), The Emerging Middle Class in Africa, Routledge, African Development Bank.

McKinsey Global Institute (2013), Lions go digital: The Internet's transformative potential in Africa, novembre 2013.

Ninot, O. et Peyroux, E. (2018), «Révolution numérique et développement en Afrique : une trajectoire singulière », Questions internationales, $n^{\circ}$ 90, mars-avril 2018, 44-52.

Ponelis, S.R. et Holmner, M.A. (2015), «ICT in Africa: Enabling a Better Life for All », Information Technology for Development, 21 (1), 1-11.

PwC (2016), "Disrupting Africa: Riding the wave of the digital revolution".

Ravallion, M. (2009), 'The Developing World’s Bulging (but Vulnerable) « Middle Class »', Policy Research Working Paper no. 4816.

Rosen, J. (2017), “Ghana's last mile”, MIT Technology Review, 120 (1).

Schwab, K. (2017), La quatrième révolution industrielle, Dunod.

Stratégies (2018), « Mobile, IA, blockchain...l'Afrique au cœur des tendances », $1^{\mathrm{er}}$ novembre 2018, 24-26.

Weigert, M. (2018), « L’invention du e-commerce africain par le secteur privé », Passerelles, Vol. 19 (2). 


\section{Annexes}

Chart 1: Average class size, as a\% of total population in 2010

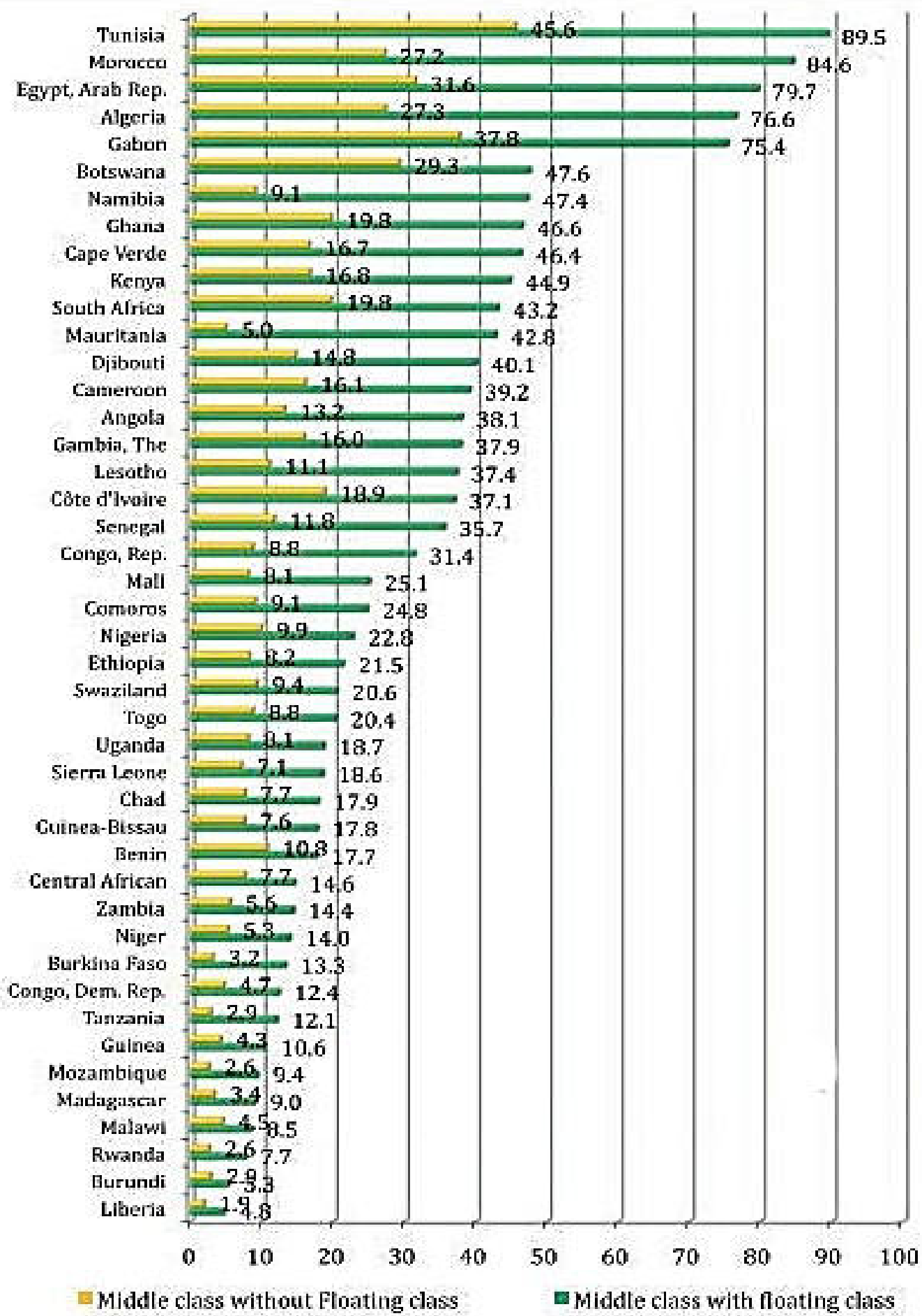

Source: BAD (2011), "The Middle of the Pyramid: Dynamics of the Middle Class in Africa", 20 avril 2011. 
Chart 2. Rationale for low e-commerce rates on a panel of five African countries

\section{Trust Most Common Reason for Low Online Shopping}

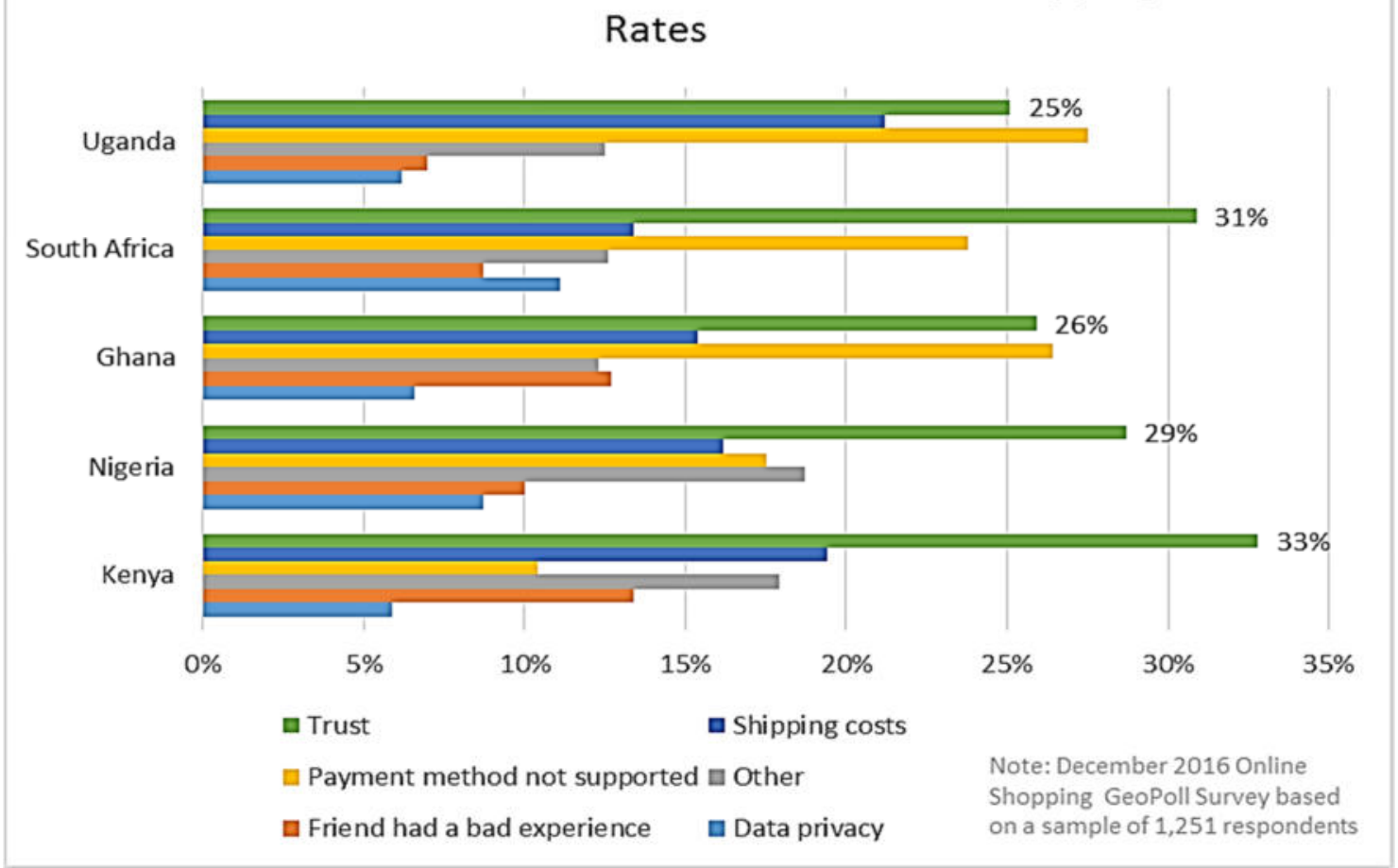


Chart 3. The Global Information Technology Report 2016 Innovating in the Digital Economy: Case of Cote d'Ivoire

\section{Côte d'lvoire}

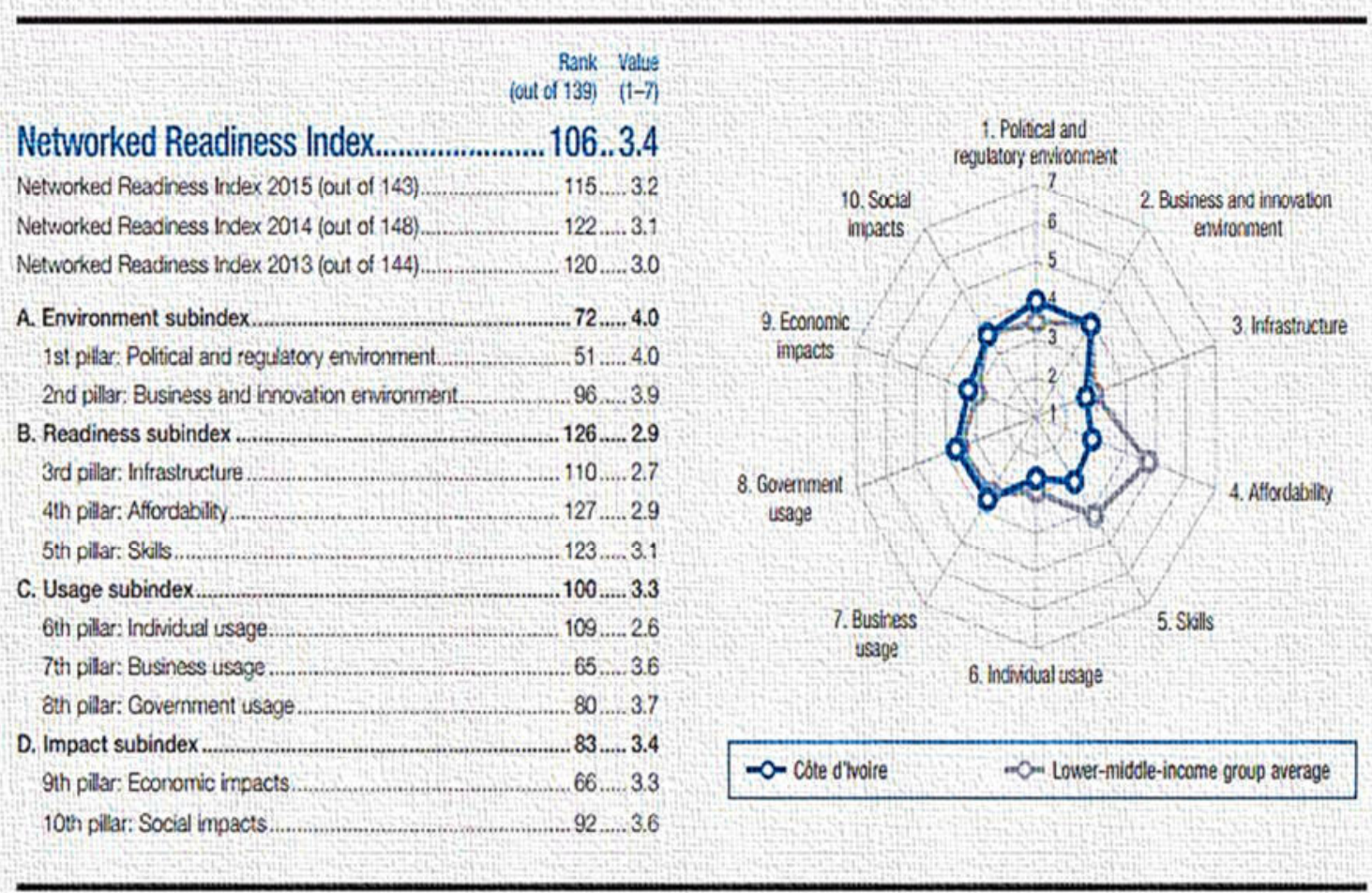

Source: The Global Information Technology Report 2016 


\section{The Networked Readiness Index in detail}

\begin{tabular}{|c|c|}
\hline & lar: Political and regulatory environment \\
\hline 01 & Effectiveness of law-making bodies ${ }^{*}$........................ \\
\hline 02 & Laws relating to $\mathrm{ICT}^{*}$....................................... 4.0 \\
\hline 03 & 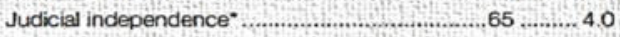 \\
\hline 04 & Etficiency of legal system in settling disputes* ....29 .........4.6 \\
\hline 05 & Etficiency of legal system in challenging regs s $^{*} . .38 \ldots \ldots . . .4 .1$ \\
\hline 06 & 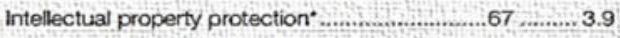 \\
\hline 07 & Software piracy rate, $\%$ software installed $\ldots \ldots \ldots .85 \ldots \ldots . .80$ \\
\hline 1.08 & No. procedures to enforce a contract _..........2 $27 \ldots \ldots . .32$ \\
\hline 1.09 & No. days to enforce a contract ................................. 525 \\
\hline & \\
\hline 2.01 & Availability of latest technologies:.......................... 4.8 \\
\hline 2.02 & 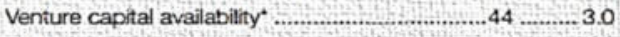 \\
\hline 2.03 & Total tax rate, $\%$ profits ......................... $117 \ldots 51.9$ \\
\hline 2.04 & No. days to start a business ............................. 42 …...... 7 \\
\hline 2.05 & No. procedures to start a business..............22 …....... 4 \\
\hline 2.06 & 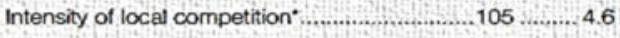 \\
\hline 2.07 & Tertiary education gross enrollment rate, $\% \ldots \ldots .118$.......... 8.7 \\
\hline & Quality of management schools \\
\hline 2.09 & Gov't procurement of advanced tech: \\
\hline
\end{tabular}

\begin{tabular}{|c|c|}
\hline & ilar: \\
\hline 01 & Eectricity production, kWh/capita..........114 _... 350.0 \\
\hline 02 & Mobile network coverage, \% pop. ................... 94 ….. 97.9 \\
\hline & Int'1 Internet bandwidth, $\mathrm{kb} / \mathrm{s}$ per user..........117 ........ 5.2 \\
\hline & Secure internet servers/million pop......................... 2.6 \\
\hline & 4th pillar: Affordability \\
\hline & Prepaid mobile cellular tarifts, PPP \$/min .......101 ...... 0.35 \\
\hline & Fixed broadband internet tariffs, PPP \$/month $117 \ldots . .79 .04$ \\
\hline & Internet \& telephony competition, $0-2$ (best) ....111 ..... 1.22 \\
\hline & 5 th pillar: Skills \\
\hline & 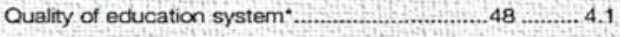 \\
\hline & Quality of math \& science education ${ }^{*} . \ldots \ldots . . . . . .17 \ldots \ldots .12$ \\
\hline & Secondary education gross enroltment rate, $\% 126 \ldots . . .40 .1$ \\
\hline & Adult iteracy rate, \% \\
\hline
\end{tabular}

\begin{tabular}{|c|c|}
\hline & 6 th pillar: Individual usage \\
\hline 6.01 & Mobile phone subscriptions/100 pop.... \\
\hline .02 & Individuals using Internet, \% .......................117 ... \\
\hline 6.03 & Households w/ personal computer. $\%$.............123... \\
\hline 04 & Households w/ Internet access, \% ....................... 12.2 \\
\hline 05 & Fixed broadband Intemet subs $/ 100$ pop $\ldots \ldots \ldots .112 \ldots . .1 . . .6$ \\
\hline 6.06 & Mobile broadband subs $/ 100$ pop $\ldots . . . \ldots \ldots \ldots . . .1 . .95 \quad 24.6$ \\
\hline 6.07 & Use of virtual social networks' $\ldots \ldots \ldots \ldots . .109$ \\
\hline & 7 th pillar: Business usage \\
\hline 7.01 & 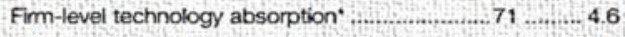 \\
\hline 7.02 & Capacity for innovation \\
\hline 7.03 & PCT patents, applications/million pop. ..........105 1........ 0.1 \\
\hline 7.04 & ICT use for business-to-business transactions $s^{*} .94 \ldots \ldots . . .4 .3$ \\
\hline 7.05 & 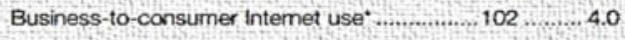 \\
\hline 7.06 & 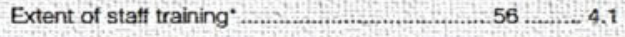 \\
\hline
\end{tabular}

8th pillar: Government usage

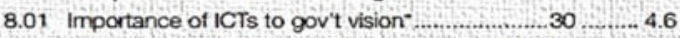

8.02 Government Ontine Service Index, $0-1$ (best) ... $114 \ldots . . .0 .17$

8.03 Gov't success in ICT promotion ......................47 ....... 4.3

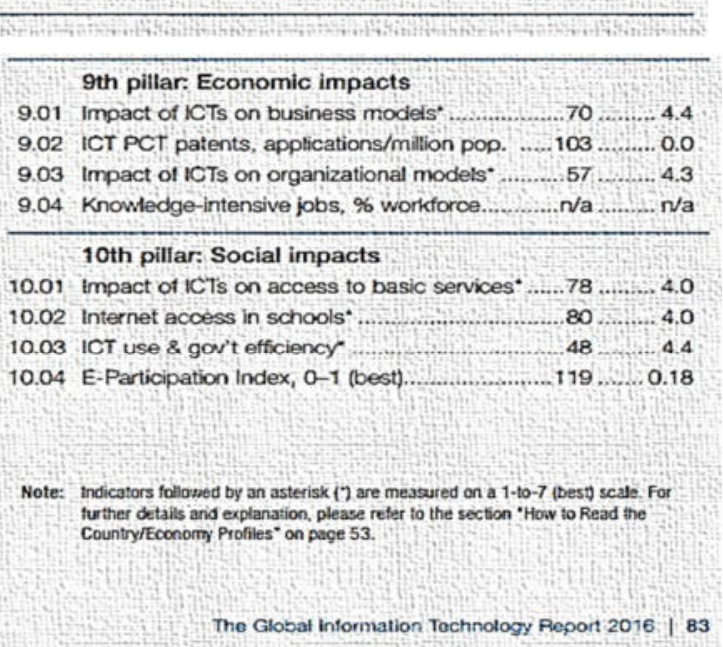

\section{ACKNOWLEDGEMENT}

First, I would like to thank Jehovah God for his guidance and the power he has given me to complete this article. I would like to express my deepest gratitude to my father and mother Guillaume and Jeannette Akouatcha without forgetting my brothers Pascal-Romuald, Guy-Youval and Régis-Claude Akouatcha for their love and support. I want to thank my friends and partner's Ingrid Epezagne and Coulibaly T. Pierrette for their encouragements. In addition, I want to show my great appreciation to my supervisor, Professor 李治文 of Jiangsu University for his invaluable advice, guidance and encouragement during the writing of this article. He provided all necessary comments and suggestions for this article. Finally, my grateful thanks also go to the person of Sir Tiemoko Berthé representative of the Minister Bruno Nabagné Koné formerly holder of the ministerial of Digital Economy and Post Now Minister of Construction, Housing, Sanitation and Urban Development. 